\title{
PRINTING HOUSE OF MAMONICHES, THE LARGEST ORTHODOX PUBLISHER OF THE EASTERN SLAVS IN THE LAST QUARTER OF 16th CENTURY - THE FIRST DECADES OF 17th CENTURY ${ }^{1}$
}

Abstract:

The article discusses the history and activities of the largest orthodox Printing house of the Grand Duchy of Lithuania. It was organized in 1574 in Vilna at the expense of the wealthy Orthodox merchants of Mamoniches and existed until 1625. For half of a century over 100 different titles were published there: theological and liturgical texts, journalistic works, textbooks, collections of legislation, publications of laws. Among the publications there were several editions of the Statute of the Grand Duchy of Lithuania, which was printed in thousands of copies. The publications of Mamoniches had a great deal influence on the cultural, political and religious development in the East and South Slavic lands.

\section{Keywords:}

Mamoniches, Pyotr Timofeev Mstislavets, Vilna, Cyril and Methodius heritage, old printed books.

АННОТАЦИЯ: Ю.А. ЛАБЫНЦЕВ. «ИЗДАТЕЛЬСКИЙ ДОМ МАМОНИЧЕЙ - КРУПНЕЙШАЯ ПРАВОСЛАВНАЯ ТИПОГРАФИЯ У ВОСТОЧНЫХ СЛАВЯН В ПОСЛЕДНЕЙ ЧЕТВЕРТИ ХVI — ПЕРВЫХ ДЕСЯТИЛЕТИЙ XVII в.».

В статье рассматривается история создания и деятельности крупнейшей православной типографии в Великом княжестве Литовском. Она была организована в 1574 г. в Вильне на средства богатейших православных купцов Мамоничей и просуществовала до 1625 г. За полвека в ней было выпущено более 100 различных изданий: богословские и литургические книги, публицистические произведения, учебники, сборники законодательных актов, издания правового характера. В их число входило несколько изданий «Статута Великого княжества Литовского», печатавшегося тысячными тиражами. Изданные Мамоничами книги оказали большое влияние на развитие культурных, политических и религиозных процессов как у восточных, так и южных славян.

\section{Ключевые слова:}

Мамоничи, издательский дом, Петр Мстиславец, Вильно, кирилло-мефодиевское наследие, старопечатные издания.

Tt was the largest printing house of the Grand Duchy of Lithuania of the 16th century, founded in 1574 in Vilna by Peter (in Belarussian - Pyotr) Timofeev Mstislavets at the expense of merchants by the name of Mamonich. During the almost half a century of its existence, it produced over 100 publi-

\footnotetext{
1 The work was carried out with the financial support of the RFBR (grant № 18-512-76004).
} 
cations of different genres, which were released in thousands of copies. These were theological and liturgical books, journalistic works, textbooks, collections of legislative acts, publications of a legal nature, including the famous Lithuanian Statute, which was published repeatedly.

In the second half of the 16th century, Vilna was a large multinational cultural and economic center in eastern Europe. After the death in 1572 of Sigismund II Augustus, the last king of the Jagiellonian family, known for his tolerant policies, the stagnation in the internal life of the young state (Rzecz Pospolita) became evident. The Catholic clergy intensified their activities, intensifying the struggle against non-believers, and the role of the Jesuits increased. In the confessional struggle for the minds of believers, the printed word began to take on greater importance, together with preaching. Each ethnocultural and ethno-confessional group or party had its own writers, its own literary environment, its own literature serving its interests, and this was reflected in the publishing policy. The backbone of the Orthodox party in Vilna was the Orthodox bourgeoisie, which subsequently initiated the creation of Orthodox fraternities. It was extremely interested in the resumption of printing, which was interrupted in $1525 \mathrm{after}$ the closure of the Vilna printing house of the Belarusian first typographer, Francisk Skorina.

In the early 1570 s, almost half a century after this sad event, printing in the city resumed. This happened thanks to the support of the wealthy merchants Kuzma and Luke Mamoniches and a wealthy Belarusian citizen by the name of Zaretsky, who were the soul of the Orthodox party in the capital of the Grand Duchy of Lithuania. Their help allowed for the opening of a printing house in the house of Mamoniches, organized by Pyotr Timofeev Mstislavets, a Belarusian colleague of the first Russian typographer, Ivan Fyodorov. The first Cyrillic books published in it were The Four Gospels (1575), The Psalter (1576), and The Chapel (presumably 1574-76). In composition, all three editions by Pyotr Mstislavets were traditional. Their text and ornamentation were very reminiscent of Moscow: up to the accompanying books of epilogues, sustained by the typographer in the style of the Moscow first printing.

In 1576 Stephen Bathory, a supporter of strong power, who spoke in words of tolerance but in fact pursued a tough policy of counter-reformation, was elected King of the Polish-Lithuanian Commonwealth. The Catholic Church, and above all the Jesuits, used all legal means to struggle against the Orthodox, including the abolition of the principle of equal ethno-confessional party representation in local bodies of the city authorities and the magistrate. In 1576 a conflict arose between Peter Mstislavets and the Mamoniches, resulting in a trial. The trial lasted about three years and ended with the published books being awarded to the Mamoniches and all of the printing equipment to Mstislavets. After that, the typographer left the city, and his further fate remains unknown.

The Mamoniches proved themselves to be enterprising and successful traders: they received a noble title for their services and were granted a royal charter 
for their printing house (giving them the right to print and sell Slavic books), guaranteeing the success of its activities. Behind the Mamoniches stood the Orthodox petite bourgeoisie of one of the largest cities in eastern Europe and the Orthodox throughout the Grand Duchy of Lithuania. The facts of the oppression of the Orthodox in the Polish-Lithuanian Commonwealth immediately became known in Russia, which closely monitored the situation of its co-religionists in neighboring countries. The Mamonich House had extensive pan-European ties with a focus on the Orthodox regions. In Moscow the firm had a kind of representative office; its sales agents were sent to the Balkans, engaged in the distribution of the books of the owners.

The typographer' shop of the House of Mamoniches resumed its activity only in 1583. Apparently, it got none of Pyotr Mstislavets' printing equipment. The Mamoniches bought equipment for it in different places in the Commonwealth and, possibly, in Russia. Grin Ivanovich, a pupil and employee of Ivan Fyodorov, accepted their invitation to work for them for a time and made them two fonts. Five years later, the new printing house had at least three printing presses and a variety of typefaces. In all ways, the Mamonich printing house was superior to all of the other printing houses of the Grand Duchy of Lithuania of the 16th and early 17 th centuries. Its publications were bought with enthusiasm, and they quickly spread throughout Europe, primarily in Russia and the Balkans. The Mamoniches sought to establish a publishing monopoly within the commonwealth and achieved their goal. On 13 March 1586 King Stephen Bathory granted the exclusive right to publish "Russian, Slavic and Greek books", to the "worthy men," Vilna citizens, the mayor Kuzma and the treasurer Luke Mamonich, and to sell them duty free within the commonwealth and beyond.

The first edition of the reinvigorated printing house was The Servant of 1583, the imprint of which was designated as "From the printing house of the Mamoniches." It was based on manuscript lists, the texts of which were equally suitable in all the Slavic lands, which was supposed to ensure the publication with a broad market among the eastern and southern Slavs. In it, for example, there are headpieces copied from the publications of the South Slavic typographer Bozhidar Vukovich and his followers. The Mamoniches' Servant of 1583 was indeed widely distributed in the Balkans and even made its way to Mt. Athos, where one of its copies is stored in the Hilandar monastery. Today, The Servant is considered a rather rare edition: only about 20 copies have survived.

The next publication of the Mamonich printing house, The Collection of 1585, was the most interesting in its composition. All of the works contained in it were listed on its first sheet, replacing the title. They are works translated from Greek. The publishers reported that they were printing the collection in full accordance with the manuscript that came to them earlier, that its texts had undoubted value, "and are necessary for Christian people, and appropriate for reading, studying and correcting their faith." A year later, the rare Slavic Grammar was published by the Mamonich printing house; only two incomplete copies have been pre- 
served. It was published, according to the afterword, "from the public purse of the glorious city of Ostrog" at the request of the Vilna inhabitants. In 1586, the very same year, The Psalter with Restoration was published, very reminiscent of The Psalter with the Theologian (Zabludov, 1570) and the famous Tribunal given to the inhabitants of the Grand Duchy of Lithuania by the Warsaw Seym (1581). The latter contained the law and instructions on the activities of the court of appeal in the Grand Duchy of Lithuania and was briefly referred to as the Tribunal. This publication was printed entirely in italics, similar to the Old Belarusian letter of state chancelleries. However, the most important book of the Mamonich printing house was The Statute of the Grand Duchy of Lithuania published in 1588. This document became a kind of guarantee of state autonomy and the independence of the Grand Duchy of Lithuania, its constitution and a collection of the most important laws at the same time. Under the conditions of the Union of Lublin, this was an unprecedented step in skillful diplomatic struggle of the principality with its neighbor, the Kingdom of Poland, which was united with it into one power, the Commonwealth. The Statute is a remarkable, multi-layered document with the elements of the Old Belarusian oral language; unfortunately, in practical terms it has not really been studied. In total, three editions of The Statute were published with a release date of 1588 .

Starting the following year, the typography began to produce publications in the Polish language, among which there were many Seym resolutions, various congratulatory and other compositions. Poetic Cyrillic works in the Old Belarusian language, belonging mainly to Andrey Rymsha, continued to be published. By the time the Union of Brest ended in 1596, the Mamonich printing house had produced about 40 various publications. It continued to operate successfully: the position of the Mamonich house as an international publishing center was further strengthened, and it remained close to events of national importance. The Mamonich printing house printed publications that were very different in nature and ethno-confessional orientation, such as About the Sign of the Cross by Maximus the Greek (early 1590s), The Pandectai of Nikon of the Black Mountain (1592), Hypatius Pociej's The Union (1595), Description and Defense of the Brest Church Council by Peter Skarga (1597). With the release of the latter, a new, Uniate, stage in the activities of the formerly Orthodox "brothers" Mamonich begins. However, further down the line they produced quite a lot of purely Orthodox publications, which found great sales both within the state and beyond. Some of the Mamonich books were reprinted from Moscow editions, which were then resold at great profit. The most significant stream of Mamonich publications was distributed in Russia in the 1590s, when the printing house used type faces of Moscow drawing, very reminiscent of Fyodorov's.

From the beginning of the 17 th century, the publishing house printed exclusively Uniate editions - there were practically no books for the Orthodox. In 1607 the printing house was inherited by Leo Mamonich, who had converted to the Uniate faith, and from 1609 onward his name was included in the output 
published by the printing house. In total, over the course of its half-century history, the Mamonich printing press published about 100 publications, making it one of the largest in the Slavic world and the most significant printing house of the 16th and early years of the 17 th century printing in the Cyrillic script.

Translated by Igor Kaliganov

\section{BIBLIOGRAPHY}

Zernova A.S. Tipografia Mamoničej v Vil'ne (XVII vek) // Kniga: Issledovania i materialy. Sb. 1. Moskva, 1959.

Labyncau Ju. Pačataje Skarynam. Drukavanaja litaratura epochi Reniessansu. Minsk, 1990.

Makišev V. Kirilličeskie izdaniaj Litovskogo Statuta 1588 goda. Krakov, 2014.

\section{ILLUSTRATIONS}

1. The title page of The Four Gospels. Vilna, 1575.

2. Matthew the Evangelist. Engraving of The Four Gospels. Vilna, 1575.

3. The title page The Psalms. Vilna, 1583.

4. The Servant. Vilna, 1583. Sheet 214.

5. The last sheet of the afterword. The Servant. Vilna, 1583.

6. The title page of The Collection. Vilna, 1585.

7. The output sheet The Grammar of the Slavic language. Vilna, 1586.

8. The title page of The Tribunal by the layman of the Grand Duchy of Lithuania. Vilna, 1586.

9. The first sheet of the appeal of Leo Sapega in The Statute of the Grand Duchy of Lithuania. Vilna, 1588.

10. The title page of The Statute of the Grand Duchy of Lithuania. Vilna, 1588 [1592/1593]. 2nd edition. 